\title{
Exposure of Workers of Ectatomma brunneum Smith (Hymenoptera: Formicidae: Ectatomminae) to ant Baits Containing Different Active Ingredients under Laboratory Conditions
}

\author{
Viviane Cristina Tofolo, Edilberto Giannotti ${ }^{\circledR}$ Marcos Aparecido Pizano
}

Universidade Estadual Paulista Júlio de Mesquita Filho, Instituto de Biociências de Rio Claro, e-mail: vivitofolo@yahoo.com.br, edilgian@rc.unesp.br (Autor para correspondência ${ }^{\bowtie}$ ), mapizano@rc.unesp.br.

\section{EntomoBrasilis 8 (1): 38-44 (2015)}

Abstract. This work evaluated the short-range mortality of workers of Ectatomma brunneum Smith when exposed to ant baits in laboratory, in order to verify if the attractiveness of this non-target species by ant baits intended to be used in the control of leaf-cutting (target) ants might be harmful to the population studied. Workers were exposed in laboratory for 48 hours to ant baits used in pastures to control the leaf-cutting ants Atta capiguara Gonçalves (Formicidae: Attini) and Atta bisphaerica Forel (Formicidae: Attini), the major species that cause damage to pastures. The following formulations of granular bait ant-killer active ingredients sulfluramid $0.3 \%$, fipronil $0.003 \%$ and chlorpyrifos $0.45 \%$ were used. The experiment outline was composed by groups of 30 workers exposed to $10 \mathrm{~g}$ of moistened ant baits, using three repetitions. Daily follow-up on mortality was performed for 20 days, recording dead and intoxicated workers. The control group received only $10 \mathrm{~g}$ of moistened citric pulp. From the results achieved, survival curves as a function of observation time were plotted using the Kaplan-Meier method and compared applying the Logrank test (nonparametric) at $5 \%$ significance level. The results revealed that the three active ingredients tested were toxic and the population reduced $35.56 \%$ in the treatment with chlorpyrifos, $31.11 \%$ with sulfluramid and $30 \%$ with fipronil.

Keywords: Chlorpiryfos; Fipronil; Poneromorphs; Sulfluramid; Toxicity.

\section{Exposição de Operárias de Ectatomma brunneum Smith (Hymenoptera: Formicidae: Ectatomminae)} a Iscas Formicidas Contendo Diferentes Ingredientes Ativos em Condições de Laboratório

Resumo. Este trabalho avaliou a mortalidade a curto prazo de operárias de Ectatomma brunneum Smith expostas a iscas formicidas em laboratório, a fim de verificar se a capacidade de atração desta espécie não-alvo a formicidas destinadas ao controle de formigas cortadeiras (alvo) pode ser prejudicial para a população estudada. As operárias foram expostas em laboratório por 48 horas a iscas formicidas utilizadas em pastagens para controlar as formigas cortadeiras Atta capiguara Gonçalves (Formicidae: Attini) e Atta bisphaerica Forel (Formicidae: Attini), as principais espécies que causam danos às pastagens. Foram utilizados os seguintes ingredientes ativos: sulfluramida $0,3 \%$, fipronil $0,003 \%$ e clorpirifos $0,45 \%$. O experimento foi composto por grupos de 30 operárias expostas a $10 \mathrm{~g}$ de formicidas, usando três repetições. Foi realizado o acompanhamento diário da mortalidade durante 20 dias, registrando-se o número de operárias mortas e intoxicadas. O grupo controle recebeu apenas 1og de polpa cítrica umedecida. A partir de resultados obtidos, as curvas de sobrevivência em função do tempo de observação foram plotadas usando o método de Kaplan-Meier, e comparadas com aplicação do Logrank test (teste não-paramétrico) em nível de significância de $5 \%$. Os resultados revelaram que os três ingredientes ativos testados foram tóxicos e a população reduzida em $35.56 \%$ no tratamento com clorpirifós, $31,11 \%$ com sulfluramida e $30 \%$ com fipronil.

Palavras-Chave: Clorpirifós; Fipronil; Poneromorfas; Sulfluramida; Toxicidade.

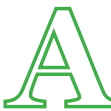

mong the economic activities performed by man, pastures occupy a remarkable area of all the physiographical regions in the country, representing the food basis for several kinds of herds (SiLvEIRA-NETO et al. 1992). As in all kinds of crops, pastures present numerous species of insects that may bring benefits or cause harm to the economy, commonly called pests. Considering the insects that cause the greatest harm, both for their lifestyle as for the damage directly occasioned, the leafcutting ants of the genera Atta and Acromyrmex are among the most important ones (MARICONI 1970).

In the current methods to control these species, the usage of granular baits has stood out (ZANúNCIO et al. 1980), mainly for offering the handlers more safety (Loeck \& NAKANO 1984), lower labor costs and higher yield in the field (ForTI et al. 1993; ZanúNCIO et al. 1993). In spite of this, the low attractiveness of the bait matrices - usually citric pulp - may lead to non-carrying or devolution together with the waste or along the trails (BOARETTO \& Forti 1997; Delabie et al. 2000), making it available to other organisms. This way, many baits may exert their toxic effects on organisms susceptible to their active ingredients, and there are few products that are selective enough so as to kill a particular pest without affecting their natural enemies, which may cause changes in the biodiversity of agricultural systems (PIMENTEL \& LEHMAN 1993).

Ant baits used to control leaf-cutting ants in pastures usually have sulfluramid, fipronil and chlorpyrifos as active ingredients. Sulfluramid is widely used as an ant killer in the shape of attractive granular baits, at a concentration of $0.3 \%$. It affects the process of oxidative phosphorylation in the insect by acting on the mitochondria, interrupting ATP synthesis (adenosine triphosphate). Temporary loss of ATP production is lethal to insects (LARINI 1999). Fipronil, which acts as a contact insecticide and has stomach action, has been used in the control of over 250 species of pests in 60 crops. It acts on the central nervous system of insects by blocking the passage of chloride ions through the chloride channels, regulated by GABA (gamma-aminobutyric

Funding Agency: CNPq (Conselho Nacional de Desenvolvimento Científico e Tecnológico). 
acid), an important neurotransmitter (Pesticide Action Network 2000). Chlorpyrifos, an organophosphorous insecticide, is toxic to a wide variety of beneficial arthropods, including bees, ants, ladybugs, and wasps, among others (Cox 1995). It inhibits the action of several enzymes, mainly acetylcholinesterase, an enzyme that controls the hydrolysis of acetylcholine, an important neurotransmitter. Thus, in the absence of acetylcholinesterase, acetylcholine released accumulates and prevents soft transmission of nervous impulses through the synaptic vesicle pathway, causing the central nervous system to collapse (LARINI 1999).

Among the insects found in pastures that cause no harm is Ectatomma brunneum Smith (Hymenoptera, Formicidae, Ectatomminae), an ant widely distributed in Latin America, occurring from Panama to Argentina (BROwN-JR 1958) and, according to KEMPF (1972), in all regions in Brazil, usually in open vegetation areas such as forest edges or clearings, but also in crops, pastures and secondary vegetation. Its presence in pastures was observed by KEMPF (1961), besides in fields and secondary vegetation in Suriname. The nests studied by Overal (1986) were found in pastures, fields and road edges, and SANTANA-REIS \& SANTOS (2001) could observe nests in pastures of Brachiaria decumbens Stapf. According to Tofolo \& GiannotTi (2005), its colonies in laboratory showed to be very resistant, with some workers surviving over 600 days. This means that, under ideal conditions, this species shows a very high average longevity, with few deaths of young individuals (the first death on the $70^{\text {th }}$ day). Once it is a generalist species, even ant baits used for leafcutting ant control in pastures become attractive and, depending on the active ingredient used, the effect may be delayed and also cumulative (RAmos et al. 2003). Decrease in individuals of $E$. brunneum was already observed even after herbicide usage in a eucalyptus area, making evident the negative impact of habitat changes upon this species regarded as non-target (RAmos et al. 2004).

This large amount of pesticides used annually worldwide, that may reach 2.5 million tons, comes in contact with biota and the environment in which they live, often causing serious harm to their populations. Studies that evaluate their effects on some species, such as non-target species, are scarce (KIELY et al. 2004).

The control of leaf-cutting ants of the genera Atta and Acromyrmex in pastures is done by using granular ant baits based on sulfluramid, fipronil and chlorpyrifos. As E. brunneum cohabits this type of environment, it turns out to be exposed to baits aiming to control only leaf-cutting ants, once it is attracted by the granular formulation that contains these active ingredients. Thus, the objective of this work was to evaluate the short-range mortality of workers of $E$. brunneum when exposed to these ant baits in laboratory, in order to verify if the attractiveness of this non-target species by ant baits intended to be used in the control of leaf-cutting (target) ants may be harmful to the population studied.

\section{MATERIAL AND METHODS}

Insects. The nests were located in open vegetation areas by following a forager to the entrance hole. Three colonies of $E$. brunneum were collected in open vegetation areas on the campus of Universidade Estadual Paulista "Júlio de Mesquita Filho", in Rio Claro, SP, Brazil, to serve as matrices for obtaining workers.

Later, these colonies were transferred to a laboratory at the biotery department, at the same institution, and housed in artificial nests made of plaster as proposed by ANTONIALLi-Junior \& GiannotTI (2002). Saturated sucrose solution at room temperature in $10 \mathrm{~cm}$ test tubes sealed with cotton, water and larvae of Tenebrio molitor Linnaeus (Coleoptera: Tenebrionidae) were offered daily in the foraging area.
The laboratory temperature was set at $23 \pm 1.8^{\circ} \mathrm{C}$ by using an airconditioning system, and the nests were kept under an artificial regime of cold light from 8 a.m. to 6 p.m. Relative air humidity was held at $70 \pm 12.4 \%$ with the aid of water containers distributed around the laboratory.

Experimental Method. Three granular bait ant-killer active ingredients were used: sulfluramid (0.3\%), fipronil (0.003\%) and chlorpyrifos (0.45\%). Each treatment was composed of 30 workers of E. brunneum, randomly taken from the three master colonies and placed in artificial nests made of plaster, as previously described. In the foraging arena, for a period of 48 hours the ants were offered water and saturated sucrose solution $\left(25^{\circ} \mathrm{C}\right)$ in 10 $\mathrm{cm}$ test tubes sealed with cotton and $10 \mathrm{~g}$ of moistened granular baits in Petri dishes (diameter $4 \mathrm{~cm}$ ). In previous studies, it was observed that ants were attracted and after ingested baits only after they were moistened in the following amounts: sulfluramid: $20 \mathrm{~mL}$, fipronil: $12 \mathrm{~mL}$ and chlorpyrifos: $10 \mathrm{~mL}$ for every $10 \mathrm{~g}$ of baits. During the observation period, no other food was offered. Ants were left without food for 24 hours before offering baits. In the control group, the procedures were the same, however, instead of the granular baits, the same matrix was offered (10 g of citric pulp pellets moistened in $30 \mathrm{~mL}$ of water) without insecticides. After this period, the ants were fed with their normal diet, based on proteins (larvae of T. molitor) and carbohydrates (saturated sucrose solution in $10 \mathrm{~cm}$ test tubes sealed with cotton). Each experiment was repeated three times, totaling 90 ants in each treatment and in the control group. The position of the dishes containing the baits was changed so as to minimize possible conditioning of the ants through the production of chemical trails.

After introducing the baits, a daily follow-up of the mortality was performed for 20 days, considering the dead and the intoxicated workers. From the results, survival curves as a function of observation time were plotted through the Kaplan-Meier method and compared applying the Logrank test (nonparametric) at 5\% significance level (ElandT-Johnson \& Johnson 1980).The differences in number of individuals between treatments were compared using repeated measures one-way ANOVA (Analysis of Variance) at $5 \%$ significance level. Pairwise a posteriori Tukey tests were used in order to determine which treatments showed significant differences.

\section{RESULTS}

Sulfluramid. The daily observations in the treatments with sulfluramid (0.3\%) showed the first death occurred in the first 24 hours of exposure and the next one only on the eighth day. At the end of 20 days, there were a total of 28 workers dead, with no statistical differences between the repetitions $(\mathrm{p}=0.628)$ (Table 1). This shows that, even after the $48 \mathrm{~h}$ of exposure, the workers of E. brunneum continued suffering from the effects of the contamination by the product, which resulted in a $31.11 \%$ decrease in the population at the end of the 20 days of observation.

Until the workers died from intoxication, the behavior of each one of them was observed so as to verify signals of contamination. Fallen on the floor, with their bodies slightly contorted, the workers moved slowly only when touched by other workers, perhaps showing impairment in energy release from ATP molecule.

Fipronil. Table 1 shows the number of dead individuals in the treatments with fipronil-based baits (0.003\%). The data show that the first death occurred only 6 days after the exposure. At the end of the 20 days of observation, the total number of dead individuals was 27 , which corresponds to $30 \%$ of the population. There was no statistical difference between the repetitions ( $p$ $=0.056$ ). These results were similar to the ones found in the treatments with sulfluramid, also demonstrating the delayed effects of this bait on ants. 
Table 1. Mortality of workers of Ectatomma brunneum after exposure for $48 \mathrm{~h}$ to sulfluramid, fipronil and chlorpyrifos. Numbers in parentheses represent the percentage of mortality. Average \pm Standard Deviation (SD) between repetitions.

\begin{tabular}{|c|c|c|c|c|c|c|c|}
\hline \multirow{3}{*}{$\begin{array}{c}\text { Days of Observation } \\
0\end{array}$} & \multicolumn{7}{|c|}{ Number of Individuals } \\
\hline & Control Group & \multicolumn{2}{|c|}{ Sulfluramid } & \multicolumn{2}{|c|}{ Fipronil } & \multicolumn{2}{|c|}{ Chlorpyrifos } \\
\hline & $90 \quad(0)$ & 90 & (o) & 90 & (o) & 90 & (o) \\
\hline 1 & $90 \quad(0)$ & 89 & $(1.11)$ & 90 & (o) & 89 & $(1.11)$ \\
\hline 2 & $90 \quad(0)$ & 89 & $(1.11)$ & 90 & (o) & 86 & $(4.44)$ \\
\hline 3 & $90 \quad(0)$ & 89 & $(1.11)$ & 90 & (o) & 86 & $(4.44)$ \\
\hline 4 & $90 \quad(0)$ & 89 & $(1.11)$ & 90 & (o) & 86 & $(4.44)$ \\
\hline 5 & $90 \quad(0)$ & 89 & $(1.11)$ & 90 & (o) & 85 & $(5.55)$ \\
\hline 6 & $90 \quad(0)$ & 89 & $(1.11)$ & 89 & $(1.11)$ & 85 & $(5.55)$ \\
\hline 7 & $90 \quad(0)$ & 89 & (1.11) & 89 & $(1.11)$ & 85 & $(5.55)$ \\
\hline 8 & $90 \quad(0)$ & 87 & $(3.33)$ & 87 & $(3 \cdot 33)$ & 82 & $(8.88)$ \\
\hline 9 & $90 \quad(0)$ & 86 & $(4.44)$ & 85 & $(5.55)$ & 78 & $(13 \cdot 33)$ \\
\hline 10 & $90 \quad(0)$ & 86 & $(4.44)$ & 85 & $(5.55$ & 78 & $(13 \cdot 33)$ \\
\hline 11 & $90 \quad(0)$ & 85 & $(5.55)$ & 85 & $(5.55)$ & 75 & $(16.66)$ \\
\hline 12 & $90 \quad(0)$ & 79 & $(12.22)$ & 85 & $(5.55)$ & 69 & $(23.33)$ \\
\hline 13 & $90 \quad(0)$ & 79 & $(12.22)$ & 85 & $(5.55)$ & 69 & $(23.33)$ \\
\hline 14 & $90 \quad(0)$ & 74 & (17.77) & 79 & $(12.22)$ & 68 & $(24.44)$ \\
\hline 15 & $90 \quad(0)$ & 74 & $(17.77)$ & 79 & $(12.22)$ & 68 & $(24.44)$ \\
\hline 16 & $90 \quad(0)$ & 71 & $(21.11)$ & 76 & $(15.55)$ & 68 & $(24.44)$ \\
\hline 17 & $90 \quad(0)$ & 71 & $(21.11)$ & 76 & $(15.55)$ & 68 & $(24.44)$ \\
\hline 18 & $90 \quad(0)$ & 71 & $(21.11)$ & 76 & $(15.55)$ & 68 & $(24.44)$ \\
\hline 19 & $90 \quad(0)$ & 65 & $(27.77)$ & 67 & $(25.55)$ & 64 & $(28.88)$ \\
\hline 20 & $90 \quad(0)$ & 62 & $(31.11)$ & 63 & (30.00) & 58 & $(35.55)$ \\
\hline Average \pm SD & $90.00 \pm 0$ & 81.10 & 9.09 & 83.14 & \pm 7.86 & 76.43 & \pm 9.58 \\
\hline ANOVA (TUKEY test) & p>0.05 ${ }^{a}$ & $\mathbf{p}>\mathbf{0}$ & $05^{b}$ & $\mathbf{p}>\mathbf{0}$ & $05^{b}$ & $\mathbf{p}>\mathbf{0}$ & $05^{\mathrm{c}}$ \\
\hline
\end{tabular}

* Different letters in superscript following values indicate statistical significant differences between averages; equal letters indicate no statistical significant differences between averages.

The workers also presented a noticeably altered behavior as a consequence of the intoxication from the exposure to the baits, and two stages of behavior could be verified. In the first stage, there was intense movement of the anterior and median pairs of legs upward and downward, which remained always outstretched; besides, they walked quickly through the foraging arena, with intense movements of their antennae and mandibles. In the second stage, they fell down and contorted their bodies, shaking intensely.

Chlorpyrifos. In the first 24 hours of exposure to baits with $0.45 \%$ chlorpyrifos only one death was observed (Table 1 ), and the most meaningful mortality happened only on the $12^{\text {th }}$ and $20^{\text {th }}$ days. At the end of the 20 days of observation, the number of dead individuals was 32 , which corresponds to $35.56 \%$ of the population, the highest value in the three treatments. There was no statistical difference between the repetitions $(p=0.052)$. In the field, MicherefF-FilHo et al. (2004) observed a significant decrease in the population of E. brunneum and other species of ants 20 days after spraying with chlorpyrifos in corn crops, reporting no signal of recovery up to 8 weeks later.

The behavior of the intoxicated individuals observed showed to be very similar to the behavior in the treatment with fipronil, with two distinct stages as well: one characterized by intense action, and the other characterized by paralysis.

The $p$ values of the Tukey test, for comparing the means in pairs, were all lower than 0.05 (Table 1), showing that the means of the four groups (three treatments and control group) were significantly different. When we comparing the results of control group with treatments, we can see that the $p$ value was significant in all cases, which means that the mortality was due to exposure of ants for 48 hours to toxic baits based on sulfluramid, fipronil and chlorpyrifos.

\section{DISCUSSION}

The loss of movement of ants and their consequent death observed on treatment with sulfluramid was similar to that observed by LARANJEIRO \& ZANÚNCIO (1995) in Atta sexdens rubropilosa Forel in eucalyptus crops. According to ForTi et al. (1993), there may be contamination of other individuals in the colony through workerworker cleaning behaviors (allogrooming), and not necessarily contamination only by direct ingestion. This behavior can be explained because one of the metabolites of sulfluramid acts in the processes of oxidative phosphorylation at the mitochondrial level, interrupting the capacity of cells to use oxygen, leading to cellular anoxia, which causes impairment of cell metabolism and ATP production, is drastically reduced. For this reason, several internal processes (such as active transport of molecules, synthesis and secretion of substances) and external processes (locomotion, feeding) become severely impaired Schnellman \& MANNing (1990).

Once it is an active ingredient with delayed effects, sulfluramid does not kill ants immediately, allowing contamination of the rest of the population (FORTI 1997) through trophallaxis (FowLER et al. 1991) or direct contact with a high number of individuals. Furthermore, the fact that ants of the genus Ectatomma feed on other living or recently-dead ants (DELABIE 1999) contributes to indirect contamination through the capture of contaminated prey. According to RAmos et al. (2003), decrease in the amount of food available in an area, after a treatment with granular baits, also contributes to the disappearance of several species of ants, which eventually causes imbalance in the ecosystem. Attraction of other non-target ant species to sulfluramid-based ant baits was already observed by RAMOs et al. (2003). These authors verified that populations of predator ants such as E. brunneum, Ectatomma edentatum Roger, Anochetus diegensis Forel, Hypoponera spp. and Megalomyrmex sp. were severely affected for up to 60 days 
after using ant baits containing $0.3 \%$ sulfluramid.

The intense movement of ants treated with fipronil was typical of the effects presented in cases of contamination by fipronil: a system blocker of the passage of chloride ions through the chloride channels that are regulated by gamma-aminobutyric acid (GABA), which, in doses high enough, causes death by hyperexcitement (GENTILE et al. 2004).

Aiming to control migratory locusts in natural vegetation areas in Nigeria and Mauritania, BALANÇA \& DE-VISSCHER (1997a, b) verified the indirect effects of fipronil on the community of ants living in that place. At the end of the 11 days of observation after fipronil spray (o.6 to $2 \mathrm{~g}$ a.i. ha-1 ${ }^{-1}$, hundreds of dead individuals, of several species, were scattered around the entrance of their nests. This mortality probably may have happened due to the contact with the vegetable substrate treated and the fact that workers carried dead locusts into the nests $48 \mathrm{~h}$ after the spray. This short-term mortality was also observed in the community of wasps. The families of solitary parasitic wasps such as Braconidae and Scelionidae, and predator wasps, such as Sphecidae, were severely affected, presenting mortality rates of $62 \%, 100 \%$ and $100 \%$, respectively. When the concentration was reduced by half, the mortality rates decreased to $35 \%, 74 \%$ and $77 \%$, respectively. Though there was an effective control of the locusts, the nontarget organisms did suffer the effects of this exposure, which caused the local relative abundance to fall, with chances of a very slow recovery.

In Australian vineyards, European wasps of the genus Vespula Thomson have caused serious occupational problems due to their stings, direct harm to the crops and loss in the wine quality. When treated with 0.025 and $0.1 \%$ fipronil-based baits, the mortality rates were $50-72 \%$ and $80 \%$, respectively, after 4 days of treatment, minimizing in the short run the problems caused (LEFOE et al. 2001). An effective control of these wasps was also obtained in Argentina by SACKMANN et al. (2004). All 46 nests spread in a 12 ha reforested area in Patagonia were eliminated at the end of the summer after treatment with fipronil-based baits (0.1\%).

The importance of bees (Apis mellifera Linnaeus) in monitoring environmental pollution is known due to their high rate of reproduction, great mobility and flight range, and pollination of about $90 \%$ of the species of plants and flowers and $80 \%$ of the vegetables of economic interest (MCGREGOR 1976). However, few studies have been performed to evaluate the effects from insecticide contamination. The presence of certain insecticide substances in honey was detected by Chauzat et al. (2006) in apiaries in France. From the 19 compounds found, fipronil and/or its metabolites were the third most frequent, present in $12.4 \%$ of the samples. The presence of metabolites in honey is possibly derived from natural photodegradation in the field or in laboratory. During the study period, no death was recorded, indicating that bees were chronically exposed to these products. It is not known for sure whether this exposure results in negative effects on these populations.

Organophosphorous compounds, like chlopyrifos, inhibit the action of several enzymes, mainly acetylcholinesterase, an enzyme that controls the hydrolysis of acetylcholine, an important neurotransmitter. Thus, in the absence of acetylcholinesterase, acetylcholine released accumulates and prevents soft transmission of nervous impulses through the synaptic vesicle pathway, causing the central nervous system to collapse (LARINI 1999). Unless a specific reactivator is used, such acetylcholinesterase inhibition is irreversible and a return to the normal levels depends on the

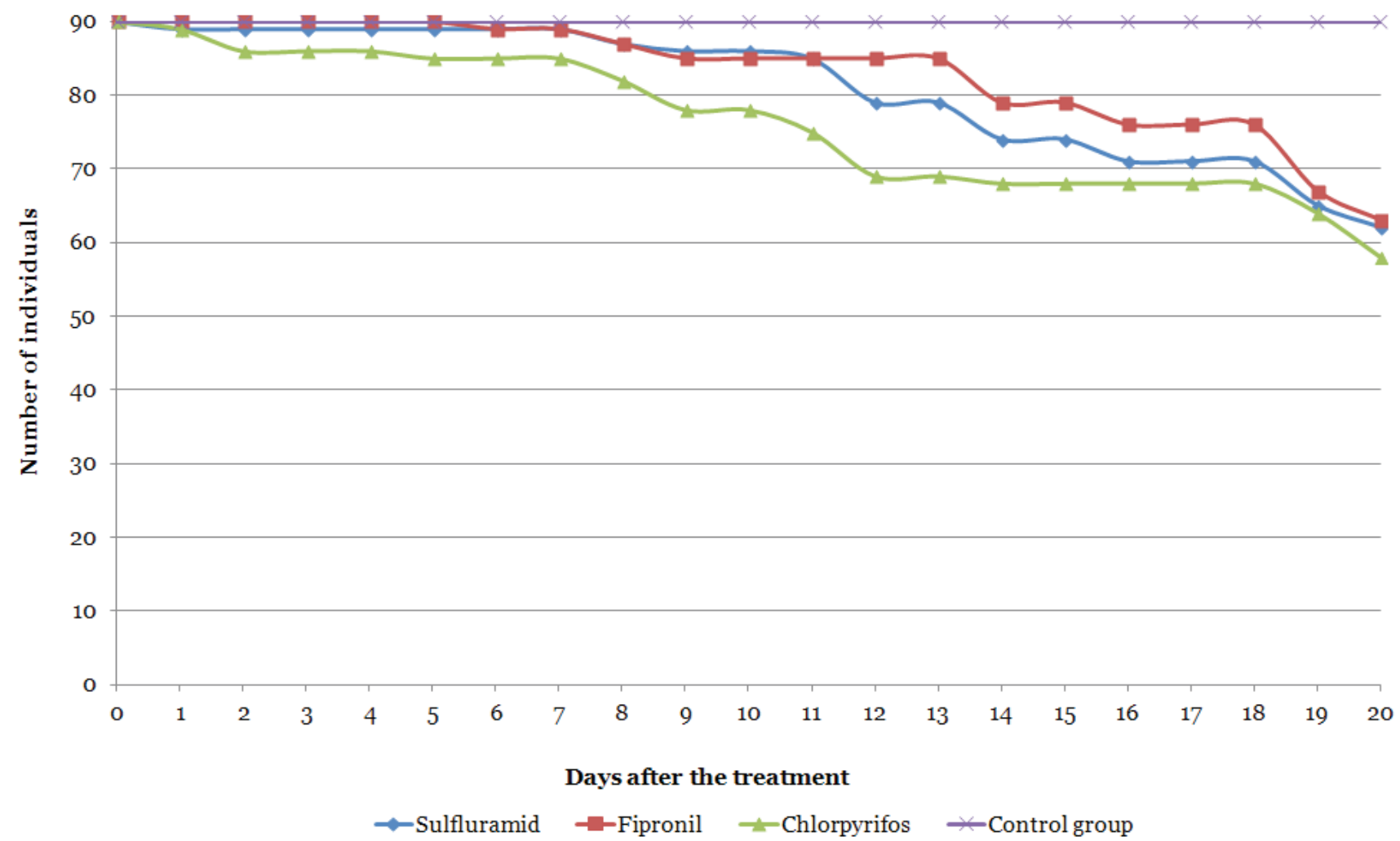

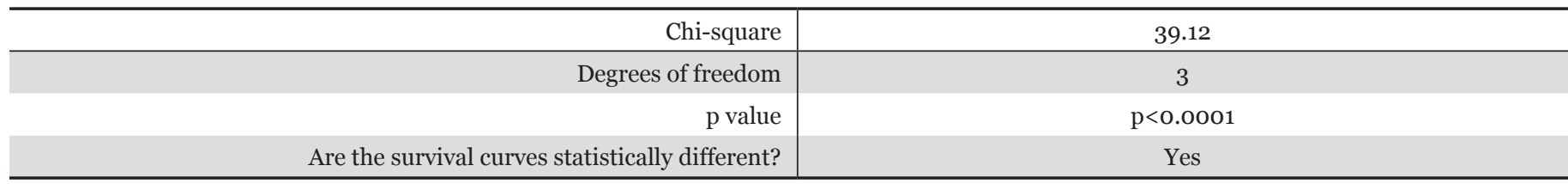

Figure 1. The result of the comparison of the mortality curves of workers of E. brunneum after 48h of exposure through the Logrank test (ELANDTJOHNSON \& JOHNSON 1980) 
synthesis of a new enzyme (LARINI 1999). This caused the behavior observed on the ants treated with chlopyrifos, which presented hyperexcitement and posteriorly paralysis.

On Brachygastra lecheguana Latreille, Polybia paulista Ihering and Protopolybia exigua Saussure, important non-target social wasps which predate on coffee leaf miner, the effects of chlorpyrifos were more severe. Only 6 hours after treatment with dry residue $(4.5 \mu \mathrm{g}$ a.i. $/ \mathrm{mL})$ in laboratory, an average mortality of $77.5 \%$ occurred in the 3 species of wasps, which corresponds to $99 \%$ of mortality of the coffee leaf miner in the same conditions (FraGoso et al. 2001).

In corn crops, ARMENTA et al. (2003) observed the total elimination of ant populations of the genus Solenopsis 15 days after spraying with chlorpyrifos. This negative effect on the foraging activity of other predator ants of the genera Crematogaster, Pheidole and Solenopsis was also observed by MicherEFF-FiLHo et al. (2002) up to 3 weeks later in areas treated with chlorpyrifos. According to Perfecto (1990), the absence of these ant other natural enemies contributed to an increase in the population of Spodoptera frugiperda J.E.Smith (Lepidoptera: Noctuidae), one of the main pests in corn crops.

Insecticides are routinely evaluated for their lethal effects on target-organisms. Nevertheless, little attention is given to their sublethal effects, especially on non-target organisms. Males of Trichogramma brassicae Bezdenko (Hymenoptera: Trichogrammatidae) showed a decrease in their reaction to the sex pheromone released by females after treatment with chlorpyrifos. This is probably due to the disturbance of the interpretation of the signal that represents the pheromone, once organophosphorous insecticides (the chemical group to which chlorpyrifos belongs) act in the central nervous system at the synaptic level, harming communication between the neurons. Females also suffered from the effects of the exposure to this insecticide, reducing considerably the release of this pheromone for nervous disturbances (DELPUEch et al. 1998). The contamination caused by insecticides probably extends to other communication pheromones in several species of non-target organisms. In another species, Trichogramma pretiosum Riley, a parasitoid of Helicoverpa zea (Boddie) (Lepidoptera: Noctuidae), the treatment with chlorpyrifos did not decrease significantly the population; however, the number of parasited eggs decreased to about 53-75\% (MicheREFF-FilHo et al. 2002).

The survival curves of the treatments as a function of time are presented in Figure 1. In the control group, no death was recorded; however, the delayed and cumulative effects of the products could be verified through the low initial mortality up to the 10 first days, after which it intensified in the treatments with chlorpyrifos. The three insecticides affected negatively the populations of $E$. brunneum after the 20 days of observation, and the product that caused the highest mortality was chlorpyrifos, followed by sulfluramid and fipronil.

The comparison of the three treatments through the Logrank Test showed that there is a significant difference between the survival curves $(\mathrm{p}<0.0001)$ in relation to the control group. Though the final number of dead individuals was similar in the three treatments, the curves that represent the mortality of the individuals as a function of time in the treatments with fipronil and chlorpyrifos were statistically different $(\mathrm{p}<0.05)$.

Once it is an organophosphorous pesticide, chlorpyrifos may present a half-life of several months (LARTIGES \& GARRIGUES 1995), which might explain its higher influence on the mortality of ants even several days after it is removed from baits. Furthermore, high volatilization rates of chlorpyrifos were already observed in the first days of exposure of the product in the presence of light (LEISTRA et al. 2006), which did not occur with fipronil (NGIM \& Crosby 2001). As the ants had the habit of taking the baits into the nests, the air present in the chambers might have become saturated with chlorpyrifos, and the aggravating high intranest humidity makes its degradation even slower (AwASTHI \& PRAKASH 1999), exposing the individuals for much longer. In the field, such characteristic of fast volatilization may be one of the factors that make chlorpyrifos less effective in the control of some insect species regarded as pests (MeIKLE et al. 1983).

In the experiments carried out in laboratory, the workers of E. brunneum were not repelled by the ant baits under normal exposure conditions. However, their attractiveness was not enough so as to induce ants to carry or ingest them. When this material was moistened, the attractiveness increased significantly, allowing portions of the baits to be ingested still in the foraging arena or taken into the nest and distributed to the other individuals. In none of the treatments total or partial devolution of the portions carried was observed. The comparison between the 3 treatments through the Logrank test revealed there is a significant difference between the survival curves and the control group after the $48 \mathrm{~h}$ of exposure to the ant baits, and the product that caused the highest mortality was chlorpyrifos, followed by sulfluramid and fipronil.

This corroborates some results already observed in which it was reported that this species of ant, regarded as non-target, may be attracted by ant baits destined for control of other insects that cause harm to agrosystems, according to the conditions found in the field and application method. If the recommendations provided for the application of each product are not properly followed, there is the possibility that not only this species, but other generalist species, are attracted by the baits, which may cause undesirable effects on these populations.

There is a need to develop new methodologies to be employed in laboratory tests aiming at a contact between non-target ants and ant baits used in the field. Studies in this area are scarce, which makes standardization of experiments difficult. Thus, this work contributed to an understanding of what are the effects of some chemical substances on the predator ant species studied, besides proposing a laboratory methodology to test ant baits in non-target organisms.

\section{ACKNOWLEDGMENTS}

The authors thank CNPq (Conselho Nacional de Desenvolvimento Científico e Tecnológico) for financial support and the company CITROSUCO Fisher S/A - Agroindústria, in the cities of Limeira and Matão, SP, Brazil, for supplying the orange pulp pellets used in this experiment.

\section{REFERENCES}

Antonialli-Junior, W. \& E. Giannotti, 2002. Division of labor in Ectatomma edentatum (Hymenoptera: Formicidae). Sociobiology, 39: 37-63.

Armenta, R., A.M. Martinez, J.W. Chapman, R. Magallanes, D. Goulson, P. Caballero, R.D. Cave, J. Cisneros, J. Valle, V. Castillejos, D.I. Penagos, L.F. García \& T. Williams, 2003. Impact of a nucleopolyhedrovirus bioinsecticide and selected synthetic insecticides on the abundance of insect natural enemies on maize in Southern Mexico. Journal of Economic Entomology, 96:649-661.

Awasthi, M.D. \& N.B. Prakash, 1999. Persistence of Chlorpyrifos in Soils under Different Moisture Regimes. Pest Management Science, 50: 1-4.

Balança, G \& M.N. de-Visscher, 1997a. Effects of very low doses of fipronil on grasshoppers and non-target insects following field trials for grasshopper control. Crop Protection, 16: 553564.

Balança, G \& M.N. de-Visscher, 1997b. Impacts on nontarget insects of a new insecticide compound used against the desert locust Schistocerca gregaria (Forskål 1775). Archives of 
Environmental Contamination and Toxicology, 32: 58-62.

Boaretto, M.A.C. \& L.C. Forti, 1997. Perspectivas no controle de formigas cortadeiras. Série Técnica IPEF, 11: 31-46.

Brown-Jr., W.L., 1958. Contributions toward a reclassification of the Formicidae. II. Tribe Ectatommini (Hymenoptera). Bulletin of the Museum of Comparative Zoology, 118: 175362.

Chauzat, M.P., J.P. Faucon, A.C. Martel, J. Lachaize, N. Cougoule \& M Aubert, 2006. A survey of pesticide residues in pollen loads collected by honey bees in France. Journal of Economic Entomology, 99: 253-262.

Cox, C., 1995. Chlorpyrifos: Ecological Effects. Journal of Pesticide Reform, 15: 1-19.

Delabie, J.H.C., 1999. Comunidades de formigas (Hymenoptera: Formicidae): métodos de estudo e estudos de casos na Mata Atlântica. Anais do Encontro de Zoologia do Nordeste.5868.

Delabie, J.H.C., T.M.C. Della-Lúcia \& L. Pastre, 2000. Protocolo de experimentação para avaliar a atratividade de novas formulações de iscas granuladas utilizadas no controle de formigas cortadeiras Acromyrmex spp. e Atta spp. (Hymenoptera: Formicidae: Myrmicinae: Attini) no campo. Anais da Sociedade Entomológica do Brasil, 29: 843-848.

Delpuech, J.M., B. Froment, P. Fouillet, F. Pompanon, S. Janillon \& M. Boulétreau, 1998. Inhibition of sex pheromone communications of Trichogramma brassicae (Hymenoptera) by the insecticide chlorpyrifos. Environmental Toxicology and Chemistry, 17: 1107-1113.

Elandt-Johnson, R. \& N. L. Johnson, 1980. Survival models and data analysis. New York, John Wiley and Sons, 457p.

Forti, L.C., 1997. Formigas cortadeiras: distribuição geográfica, biologia, ecologia e danos. Reciclagem sobre formigas cortadeiras. Curitiba, SENAR. 41p.

Forti, L.C., T.M.C. Della-Lucia, W.K. Yassu, J.M.S. Bento \& M.A.S. Pinhão, 1993. Metodologias para experimentos com iscas granuladas para formigas cortadeiras, p. 191-211. In: Della-Lucia T.M.C. (Ed.) As formigas cortadeiras. Viçosa, Folha de Viçosa, 262p.

Fowler, H.G., L.C. Forti, C.R.F. Brandão, J.H.C. Delabie \& H.L. Vasconcelos. 1991. Ecologia nutricional de formigas, p. 131-223. In: Panizzi A.R. \& J.R.P. Parra (Eds.). Ecologia nutricional de insetos e suas implicações no manejo de pragas. São Paulo, Manole, 359p.

Fragoso, D.B., P. Jusselino-Filho, R.N.C. Guedes \& R. Proque, 2001. Seletividade de inseticidas a vespas predadoras de Leucoptera coffeella (Guér.-Mènev.) (Lepidoptera: Lyonetiidae). Neotropical Entomology, 30: 139-144.

Gentile, A.G., J.L. Sartini, M.C. Campo \& J.F, Sánchez, 2004. Eficacia del fipronil en el control del ciclo peridomiciliario de Triatoma infestans en un área con resistência a la Deltametrina. Caderno de Saúde Pública, 20: 1240-1248.

Kempf, W.W., 1961. A survey of the ants of the soil fauna in Surinam (Hymenoptera: Formicidae). Studia Entomologica, 4: 481-524.

Kempf, W.W., 1972. Catálogo abreviado das formigas da região neotropical (Hymenoptera: Formicidae). Studia Entomologica, 15: 1-344.

Kiely, T., D. Donaldson \& A. Grube, 2004. Pesticides industry sales and usage: 2000 and 2001 market estimates. Washington, DC, U.S. Environmental Protection Agency, 48p.

Laranjeiro, A.J. \& J.C. Zanúncio, 1995. Avaliação da isca à base de sulfluramida no controle de Atta sexdens rubropilosa pelo processo de dosagem única de aplicação. IPEF 48/49: 144152.

Larini, L., 1999. Toxicologia dos praguicidas. São Paulo, Editora Manole Ltda, 230p.

Lartiges, S.B. \& P.P. Garrigues, 1995. Degradation kinetics of a organophosphorus and organonitrogen pesticides in different waters under various environmental conditions. Environmental Science \& Technology, 29: 1246-1254.

Lefoe, G., D. Ward, P. Honan, S. Darby \& K. Butler, 2001.
Minimising the impact of European wasps on the grape and wine industry. Final report to Grape and Wine Research \& Development Corporation DAV 99/1.

Leistra, M., J.H. Smelt, J.H. Weststrate, F. van-den-Berg \& R. Aalderink, 2006. Volatilization of the pesticides chlorpyrifos and fenpropimorph from a potato crop. Environmental Science \& Technology, 40: 96-102.

Loeck, A.E. \& O. Nakano, 1984. Efeito de novas substâncias visando o controle de sauveiros novos de Atta laevigata (Smith, 1858) (Hymenoptera: Formicidae). O solo, 76: 2530.

Mariconi, F.A.M., 1970. As saúvas. São Paulo, Editora Agronômica Ceres, $167 \mathrm{p}$.

McGregor, S.E., 1976. Insect pollination of cultivated crop plants. Washington: USDA, (Agriculture Handbook, 496), 411p.

Meikle, R.W., N.H. Kurihara \& D.H. Devries, 1983. Chlorpyrifos: the photodecomposition rates in dilute aqueous solution and on a surface, and the volatilization rate from a surface. Archives of Environmental Contamination and Toxicology, 12: $189-193$.

Michereff-Filho, M. T.M.C. Della-Lucia, I. Cruz, R.N.C. Guedes \& J.C.C. Galvão, 2002. Chlorpyrifos spraying of no-tillage corn during tasselling and its effect on damage by Helicoverpa zea (Lepidoptera: Noctuidae) and on its natural enemies. Journal of Applied Entomology, 126: 422-430.

Michereff-Filho, M., R.N.C. Guedes, T.M.C. Della-Lucia, M.F.F. Michereff \& I. Cruz, 2004. Non-target impact of chlorpyrifos on soil arthropods associated with no-tillage cornfields in Brazil. International Journal of Pest Management, 50: 9199.

Ngim, K.K. \& D.G. Crosby, 2001. Abiotic processes influencing fipronil and desthiofipronil Dissipation in California, USA, rice fields. Environmental Toxicology and Chemistry, 20: 972-977.

Overal, W.L., 1986. Recrutamento e divisão de trabalho em colônias naturais da formiga Ectatomma quadridens (Fabr.) (Hymenoptera: Formicidae: Ponerinae). Boletim do Museu Paraense Emilio Goeldi Zoologia, 2: 113-135.

Perfecto, I., 1990. Indirect and direct effects in a tropical agroecosystem: the maize-pest-ant system in Nicaragua. Ecology, 71: 2125-2134.

Pesticide Action Network, UK (PAN), 200o. Fipronil. Pesticide News 48: 20.

Pimentel, D. \& H. Lehman, 1993. The pesticide question Environment, economics and ethics, p. 13-46. In: Edwards C.A. (Ed.). The impact of pesticides on the environment. London and New York, Chapman \& Hall, 441p.

Ramos, L.S., C.G.S. Marinho, R. Zanetti, J.H.C. Delabie \& M.N. Schlindwein, 2003. Impacto de iscas formicidas granuladas sobre a mirmecofauna não-alvo em eucaliptais segundo duas formas de aplicação. Neotropical Entomology, 32: 231-237.

Ramos, L.S., R. Zanetti, C.G.S. Marinho, J.H.C. Delabie, M.N. Schlindwein \& R.P. Almado, 2004. Impacto das capinas mecânica e química do sub-bosque de Eucalyptus grandis sobre a comunidade de formigas (Hymenoptera, Formicidae). Revista Árvore, 28: 139-146.

Sackmann, P., M. Rabinovich \& J.C. Corley, 2004. Successful removal of Germanyellowjackets (Hymenoptera:Vespidae) by toxic baiting. Instituto Nacional de Tecnología Agropecuaria, Comunicaciones Técnicas.

Santana-Reis, V.P.G. \& G.M.M. Santos, 2001. Influência da estrutura do habitat em comunidades de formigas (Hymenoptera, Formicidae) em Feira de Santana, Bahia, Brasil. Sitientibus Série Ciências Biológicas, 1: 66-70.

Schnellman, R.G. \& R.O. Manning, 1990. Perfluooctane sulfonamide: a structure novel uncoupler of oxidative phosphorylation. Biophysica Acta, 1060: 344-348.

Silveira-Neto, S., L.C. Marchini \& S.B. Alves, 1992. Pragas das pastagens. Curso de Entomologia Aplicada à Agricultura. Piracicaba, FEALQ, 335p.

Tofolo, V.C. \& E. Giannotti, 2005. Population dynamics of 
Ectatomma brunneum (Hymenoptera: Formicidae) under laboratory conditions. Sociobiology, 46: 627-636.

Zanúncio, J.C., E.F. Vilela \& S.B. Nogueira, 1980. Emprego de iscas granuladas e pós-secos no controle de Atta laevigata, no município de Curvelo. Revista Árvore, 4: 221-226.

Received in: 04/29/2014

Accepted in: 02/05/2015

Zanúncio, J.C., L. Couto, T.V. Zanúncio \& M. Fagundes, 1993. Eficiência da isca granulada Mirex-S (sulfluramida 0,3\%) no controle da formiga-cortadeira Atta bisphaerica Forel (Hymenoptera: Formicidae). Revista Árvore, 17: 85-90.

\section{Suggested citation:}

Tofolo, V.C., E. Giannotti \& M.A. Pizano, 2015. Exposure of Workers of Ectatomma brunneum Smith (Hymenoptera: Formicidae: Ectatomminae) to ant Baits Containing Different Active Ingredients under Laboratory Conditions. EntomoBrasilis, 8 (1): 38-44.

Accessible in: doi:10.12741/ebrasilis.v8i1.437
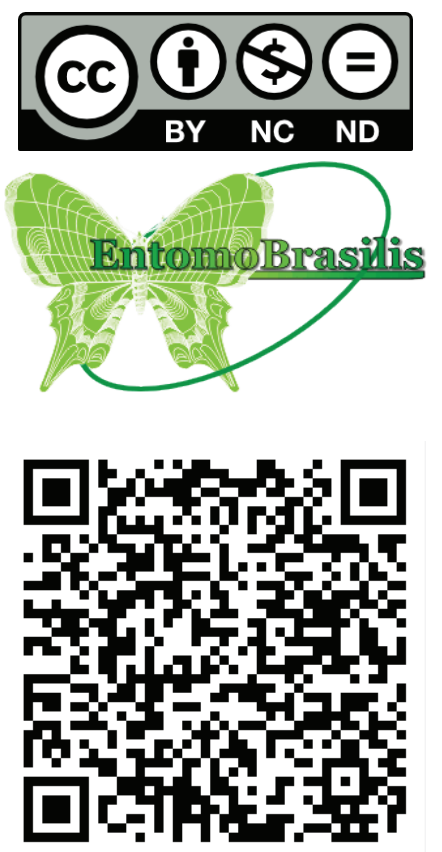